\title{
Interannual variability of the upper ocean carbon cycle in the northeast Atlantic Ocean
}

\author{
Melchor González-Dávila, ${ }^{1}$ J. Magdalena Santana-Casiano, ${ }^{1}$ \\ and Enrique F. González-Dávila ${ }^{2}$ \\ Received 12 September 2006; revised 5 March 2007; accepted 13 March 2007; published 12 April 2007.
}

[1] Surface waters in the subtropical gyres have persistently absorbed anthropogenic $\mathrm{CO}_{2}$ at a rate such that their inorganic carbon concentrations have shown a clear upward trend. We report a 10-year time series of upper-ocean inorganic carbon observations from the northeastern subtropical Atlantic at ESTOC which indicates significant variability in the inorganic carbon fluxes produced by variations in the Winter mixed-layer depths, induced by sea surface temperature anomalies. This variability reflects fluctuations relating to the NAO for both sites of the sub-tropical gyre, with the Eastern part showing a closer correlation with a 3-year NAO delay. The response to interannual variations in the meteorological forcing to the extra-tropical carbon cycle can be predicted to clarify effects on future climate change. Citation: González-Dávila, M., J. M. Santana-Casiano, and E. F. González-Dávila (2007), Interannual variability of the upper ocean carbon cycle in the northeast Atlantic Ocean, Geophys. Res. Lett., 34, L07608, doi:10.1029/2006GL028145.

\section{Introduction}

[2] Human activities such as the burning of fossil fuels, land-use changes, and cement production have emitted large quantities of $\mathrm{CO}_{2}$ into the atmosphere, producing an evolution from 280 parts per million by volume (ppm) prior to the Industrial Revolution, to the current level of $380 \mathrm{ppm}$ [Keeling and Whorf, 2000; Houghton, 2003]. During these 250 years, only half of the $\mathrm{CO}_{2}$ released by these anthropogenic processes has remained in the atmosphere [Sarmiento and Gruber, 2002; Sabine et al., 2004]. The ocean's role in the global carbon cycle has recently been addressed, with the estimation of an anthropogenic carbon dioxide sink, for the period from 1800 to 1994, of $118 \pm$ 19 petagrams of carbon [Sabine et al., 2004]. The increased emission of atmospheric $\mathrm{CO}_{2}$ proportionately augments the surface ocean $p \mathrm{CO}_{2}$, affecting the carbonate speciation in seawater, which decreases the ability of the ocean to absorb more $\mathrm{CO}_{2}$, due to the increase in the Revelle factor and a decrease in the $\mathrm{pH}$ of the surface waters, with acidification of the oceans already experimentally observed [GonzálezDávila et al., 2003; Santana-Casiano et al., 2007].

[3] The increase of atmospheric $\mathrm{CO}_{2}$ is not constant [Keeling et al., 1995]. The oceanic carbon cycle also

\footnotetext{
${ }^{1}$ Chemistry Department, Faculty of Marine Science, University of Las Palmas Gran Canaria, Las Palmas de Gran Canaria, Spain.

${ }^{2}$ Statistical Department, Faculty of Mathematics, University of La Laguna, La Laguna, Tenerife, Spain.

Copyright 2007 by the American Geophysical Union. 0094-8276/07/2006GL028145
}

displays a substantial interannual to decadal variability [González-Dávila et al., 2003; Santana-Casiano et al., 2007; Gruber et al., 2002; Takahashi et al., 2002; Bates et al., 2002] allowing for us to investigate how the oceanic carbon cycle might respond to future climate change [Heimann, 1995]. The North Atlantic is believed to represent the largest ocean sink for atmospheric carbon dioxide in the Northern Hemisphere, based both on observational estimates [Takahashi et al., 2002] and forward and inverse modelling results [Gloor et al., 2003]. However, little is known about the temporal variability of atmospheric carbon dioxide. Long-term time series observations have been considered critical to the documentation of the variations in the marine carbon cycle related to changes in external forcing [Gruber et al., 2002; Keeling et al., 2004]. There is a strong interannual variability over the upper ocean of the North Atlantic, which is associated with atmospheric anomalies and changes in the air-sea fluxes [Bjerkness, 1964]. The interannual anomalies of hydrography and ocean biogeochemistry are partially linked to the large scale North Atlantic climate variability index, the NAO. In the Atlantic Ocean, a positive phase of the NAO is expressed by positive SST anomalies in the subtropics and the marginal seas of Northern Europe, and negative anomalies in the sub-polar gyres, in the Canary basin, and in the Eastern tropical area. The NAO forcing may change the transport in the subtropical gyre, resulting in a variation in the Azores Current transports. In the Eastern sub-tropical gyre of the Atlantic Ocean, Germany and Spain have maintained monthly resolutions within a 10-year bio-geochemical and physical data sample at the European station for Time series at the Canary Islands, ESTOC. We have addressed the surface oceanic carbon cycle near the Canary Islands, and its trends on time scales from seasonal to interannual, on the basis of a 10 -year inorganic carbon data set from the ESTOC site [GonzálezDávila et al., 2003; Santana-Casiano et al., 2007]. Our aim is to address the implications of changes in external forcing in the Atlantic Ocean, by investigating the contribution of the controlling processes, on time scales from seasonal to interannual, on the upper oceanic carbon cycle. We quantitatively deduce how biological processes, the air-sea gas exchange, vertical diffusion and entrainment, influence the observed trends in the mixed layer, and the connections with the natural mode of atmospheric pressure variation, the NAO [Hurrell, 1995].

\section{Experiment}

[4] The ESTOC sampling strategy, analytical methods, data quality control and intercalibration procedures, all appear in a previous paper [González-Dávila et al., 2003] 


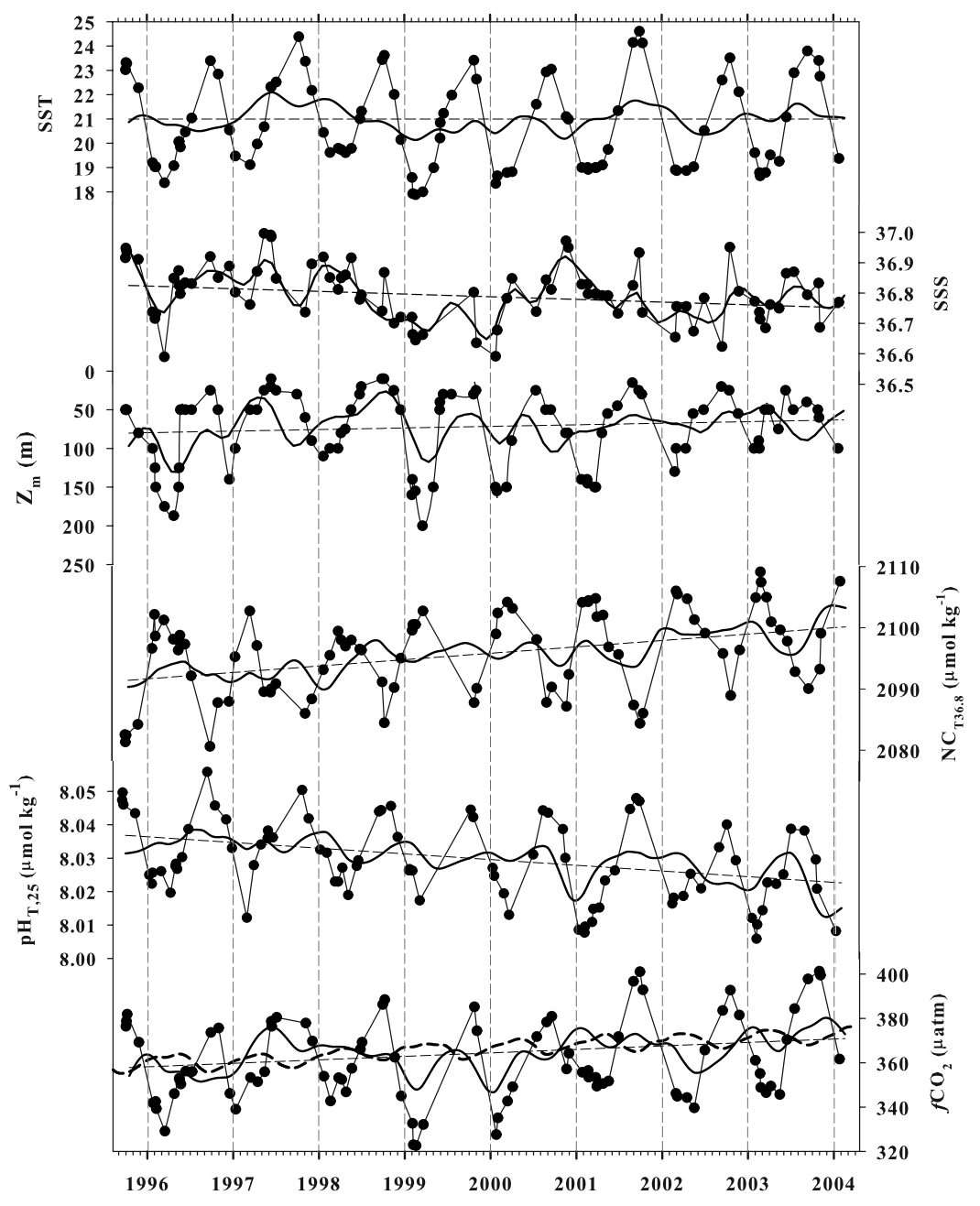

Figure 1. Time series of properties in the near surface ocean layer $(5-10 \mathrm{~m})$ of the northeast Atlantic Ocean at the ESTOC site. Observations of SST $\left({ }^{\circ} \mathrm{C}\right)$, sea surface salinity, SSS, mixed-layer depth $(\mathrm{m})$, inorganic carbon variables $\mathrm{NC}_{\mathrm{T}}(\mu \mathrm{mol}$ $\mathrm{kg}^{-1}$ ) normalized to the average salinity at ESTOC $36.8, \mathrm{pH}$ in total scale at $25^{\circ} \mathrm{C}$, and partial pressure of $\mathrm{CO}_{2}$ in seawater (circles) and in the atmosphere (dark dashed line) expressed as fugacity, $f \mathrm{CO}_{2}(\mu \mathrm{atm})$. The long-term seasonal de-trended time series of data and linear regressions has been added to emphasize trends, and is charted in the form of smoothing splines for each property.

and in the ESTOC data reports [Llinás et al., 1997, 1999]. A brief description of methods used at ESTOC is available in the auxiliary material. ${ }^{1}$

[5] In order to elucidate quantitatively the processes that influence the surface oceanic carbon cycle at ESTOC, and to determine how these processes interact to cause the observed correlations, we used a basic model that has been described in a previous work in detail [Bégovic and CopinMontegut, 2002; González-Dávila et al., 2003]. The model description, the associated error, and the equations, are available in the auxiliary material.

\section{Results and Discussion}

[6] The ESTOC seasonal oscillation, based on a 10-year time series, is shown in Figure 1 for temperature $\left({ }^{\circ} \mathrm{C}\right)$, salinity, mixed-layer depth $\left(Z_{m}\right.$ in $\left.m\right)$, computed total

${ }^{1}$ Auxiliary materials are available in the HTML. doi:10.1029/ 2006GL028145. dissolved inorganic carbon normalized to a constant salinity $\left(\mathrm{NC}_{\mathrm{T}, 36.8}, \mu \mathrm{mol} \mathrm{kg}{ }^{-1}\right)$, experimental $\mathrm{pH}$ in the total scale at $25^{\circ} \mathrm{C}\left(\mathrm{pH}_{\mathrm{T}, 25}\right)$, and fugacity of $\mathrm{CO}_{2}$ at in situ conditions $\left(f \mathrm{CO}_{2}, \mu \mathrm{atm}\right)$ obtained from near-surface waters [SantanaCasiano et al., 2007]. The seasonal $\mathrm{NC}_{\mathrm{T}}$ variation is $20-$ $25 \mu \mathrm{mol} \mathrm{kg}{ }^{-1} \mathrm{yr}^{-1}$ with a Spring (April-May) maximum, and a late Summer-Fall (September-October) minimum. The $f \mathrm{CO}_{2}$ seasonal cycle presents the characteristic minimum values $(320-330 \mu \mathrm{atm})$ in Winter, and maximum in Summer (390-400 $\mu \mathrm{atm})$, with an amplitude of 60-80 $\mu \mathrm{atm}$. The observed long-term rate of change [González-Dávila et al., 2003; Santana-Casiano et al., 2007] was highlighted by removing the mean seasonal cycle, and by subtracting harmonics with 12-, 6- and 4-months periods from the data (Figure 1). The $\mathrm{NC}_{\mathrm{T}}$ increases over the period at a rate of $0.99 \pm 0.20 \mu \mathrm{mol} \mathrm{kg} \mathrm{yr}^{-1}$ [Santana-Casiano et al., 2007]. The rate of increase of $f \mathrm{CO}_{2}$ is found to be $1.55 \pm$ $0.43 \mu \mathrm{atm} \mathrm{yr}^{-1}$, which corresponds to the expected theoretical value for the observed increase of $\mathrm{C}_{\mathrm{T}}$ in surface waters, with an average Revelle factor for the period of 
9.64, and also with an atmospheric increase of $1.7 \pm$ $0.7 \mu \mathrm{atm} \mathrm{yr}^{-1}$. The agreement between rates confirms that the sub-tropical near-surface waters are not substantially displaced from equilibrium with atmospheric $\mathrm{CO}_{2}$, due to slow mixing of surface waters with deeper water. A significant effect, which is experimentally proven in Figure 1, is the corresponding acidification of the surface waters [Raven et al., 2005] with values, over 2004, 0.02 units lower than at the beginning of the study. The $\mathrm{pH}_{\mathrm{T}, 25}$ decreased over the reported period at a rate of $0.0017 \pm 0.0005 \mathrm{pH}_{\text {units }} \mathrm{yr}^{-1}$. Figure 1 also depicts the resulting anomalies at ESTOC, alternating warmer and cooler anomalies, with extreme positive temperature cases registered in 1997 and 2001. The significant interannual variability in $\mathrm{NC}_{\mathrm{T}}$ anomalies is negatively correlated to the SST, while $\mathrm{fCO}_{2}$ anomalies are significantly and directly correlated to temperature [Santana-Casiano et al., 2007].

[7] To elucidate the mechanisms which generate the seasonal and interannual variability which influences the surface oceanic carbon cycle at the ESTOC site, we applied a quantitative model (see auxiliary material) to deduce how the biological processes, the air-sea exchange, lateral transport, entrainment, and vertical diffusion, influence the carbon cycle in the mixed layer [Bégovic and CopinMontegut, 2002; González-Dávila et al., 2003]. To highlight the interannual variability in these contributing factors, the mean seasonal cycle and long-term trends were removed, and the resulting anomalies were correlated to the natural mode of atmospheric pressure variation in the North Atlantic. After removing the contribution of lateral advective transport by using the salinity normalization, the computed source terms of the four processes considered in our model are presented in Figure 2, with mean fluxes for the period studied expressed in mmol m${ }^{-2}$ month $^{-1}$ in Figure $2 \mathrm{~b}$. The seasonal $\mathrm{NC}_{\mathrm{T}}$ cycle presents positive fluxes, with maximum values reaching $7 \mathrm{mmol} \mathrm{m}^{-3}$ month $^{-1}$ from November to February, and negative fluxes from March to October, with a decrease in the inorganic carbon content in the mixed layer, at a rate of $5 \mathrm{mmol} \mathrm{m}{ }^{-3}$ month $^{-1}$, from May-June. Once the horizontal flux contribution was removed, the processes which determine the mixing at ESTOC are the entrainment of water into the surface layer whenever the mixed layer is deepening, and the vertical diffusion across the lower boundary of the mixed layer. The diffusive flux is one order of magnitude lower that the entrainment contribution, and is higher from March-April, when the primary production is high [Neuer et al., 2002, 2007] and the density gradients are low, because the base of the mixed layer is shoaling. A second maximum is observed during the Fall, relating to the time when the base of the mixed layer is stationary, thus causing the density gradient to become very low. From the end of August onwards, $\mathrm{C}_{\mathrm{T}}$ fluxes increase, due to entrainment, with an intermediate maximum of $4 \mathrm{mmol} \mathrm{m}^{-3}$ month $^{-1}$. The greatest influence occurs when the deepening of the mixed layer is most intense and the $\mathrm{C}_{\mathrm{T}}$ gradient is high, reaching $11 \mathrm{mmol} \mathrm{m}^{-3}$ month $^{-1}$, with exceptionally high values in 1999 (also in 2000) when the mixed layer at ESTOC reached $180 \mathrm{~m}$ (160 $\mathrm{m}$ in 2000). The air-sea gas exchange induces a change in the $\mathrm{C}_{\mathrm{T}}$, ranging from -2 to $+2 \mathrm{mmol} \mathrm{m}^{-3}$ month $^{-1}$. The changes are highest in Summer, due to both the over-saturation of $\mathrm{CO}_{2}$, and the mixed-layer depth of around $20 \mathrm{~m}$. In Winter, the contribution increases the total flux to a lesser extent, due to the fact that the mixed layer is thicker.

[8] The net community production (NCP), as calculated, is negative most years, with maximum negativity from March-May, with values reaching $-10 \mathrm{mmol} \mathrm{m}^{-3}$ month ${ }^{-1}$, that is, $0.32 \mu \mathrm{mol} \mathrm{kg} \mathrm{kg}^{-1} \mathrm{~d}^{-1}$ (Figure 2b). These values are an estimate of the NCP since it is extremely difficult to determine advection and vertical mixing precisely, given that the time interval between two measurements is large in comparison to high frequency events. The annual estimate of the NCP at ESTOC, inside the depth of the mixed layer, gives a value of $3.3 \pm 0.8 \mathrm{~mol} \mathrm{~m}^{-2}$ year $^{-1}$. New production, estimated as the potential phytoplankton production fuelled by the available nitrate in the euphotic zone, ranged from 0.7 to $2.6 \mathrm{~mol} \mathrm{~m}^{-2} \mathrm{yr}^{-1}$, with the discrepancy between both estimations accounted for by over-consumption of carbon [Neuer et al., 2007]. Our estimates are similar to those reported for the BATS station, of $3.4 \pm 0.8 \mathrm{~mol} \mathrm{~m}^{-2}$ year $^{-1}$ [Gruber et al., 2002], and close to the values estimated for the ALOHA station [Keeling et al., 2004, Table 5]. The maxima in net primary production (NPP) for ESTOC [Neuer et al., 2007] are reported earlier than the other two stations, in late Winter and early Spring. The difference between both values represents the heterotrophic respiration. This would seem to indicate that this decreases relative to the NPP, from Winter to Summer. The anomaly values in late Summer and Autumn show peaks and shoulders reaching $-4 \mathrm{mmol} \mathrm{m}^{-3}$ month $^{-1}$, in line with the higher chlorophyll values determined at ESTOC, and attributed to the arrival of filament waters from the African upwelling area, and the passage of cyclonic eddies [Santana-Casiano et al., 2007; Neuer et al., 2007]. The carbon balance in the mixed layer is established as the sum of the net removal of carbon by the NCP $(3.3 \pm 0.8 \mathrm{~mol}$ $\mathrm{m}^{-2}$ year $\left.^{-1}\right)$ and the net addition of carbon by entrainment $\left(3.4 \pm 1.1 \mathrm{~mol} \mathrm{~m}^{-2}\right.$ year $\left.^{-1}\right)$ and, to a lesser degree, by diffusion $\left(0.2 \pm 0.03 \mathrm{~mol} \mathrm{~m}^{-2}\right.$ year $\left.^{-1}\right)$ and the air-sea gas exchange $\left(0.05 \pm 0.02 \mathrm{~mol} \mathrm{~m}^{-2}\right.$ year $\left.^{-1}\right)$. Regardless of the various uncertainties and margins for error, the calculations clearly demonstrate (Figure 2b) that the entrainment transport, controlled by the seasonal change of the mixed layer, in interaction with the NCP, is the major driver for the seasonal variations in $\mathrm{C}_{\mathrm{T}}$ in the mixed layer at the ESTOC site.

[9] The annual mean fluxes vary up to $\pm 40 \%$ (Figure $2 \mathrm{a}$ ). In order to focus on this interannual variability, we removed the mean seasonal cycles and trends (Figure 3), and computed the correlations between the interannual anomalies of all the available quantities (Table 1). The flux anomalies for the entrainment and the NCP exhibit substantial variability, with peak-to-peak anomalies of up to $\pm 200 \mathrm{mmol} \mathrm{m}^{-2}$ month $^{-1}\left( \pm 0.6 \mathrm{~mol} \mathrm{~m}^{-2}\right.$ year $\left.^{-1}\right)$, whereas the air-sea gas exchange and diffusive transport vary only slightly $\left( \pm 0.1 \mathrm{~mol} \mathrm{~m}^{-2}\right.$ year $^{-1}$ and $\pm 0.06 \mathrm{~mol} \mathrm{~m}^{-2}$ year $^{-1}$, respectively). These annual flux anomalies reveal that entrainment and NCP are responsible for the modifications in their respective annual mean fluxes, to a degree of 50$100 \%$. The strongest correlations between the observed quantities and the carbon flux contributors are found for the seasonal dynamics of the mixed-layer depth, $\mathrm{Z}_{\mathrm{m}}$, which, in turn, inversely correlates to the sea surface temperature anomalies ( $\mathrm{r}=-0.35)$ [Santana-Casiano et al., 2007]. Entrainment and diffusion transports show the highest 


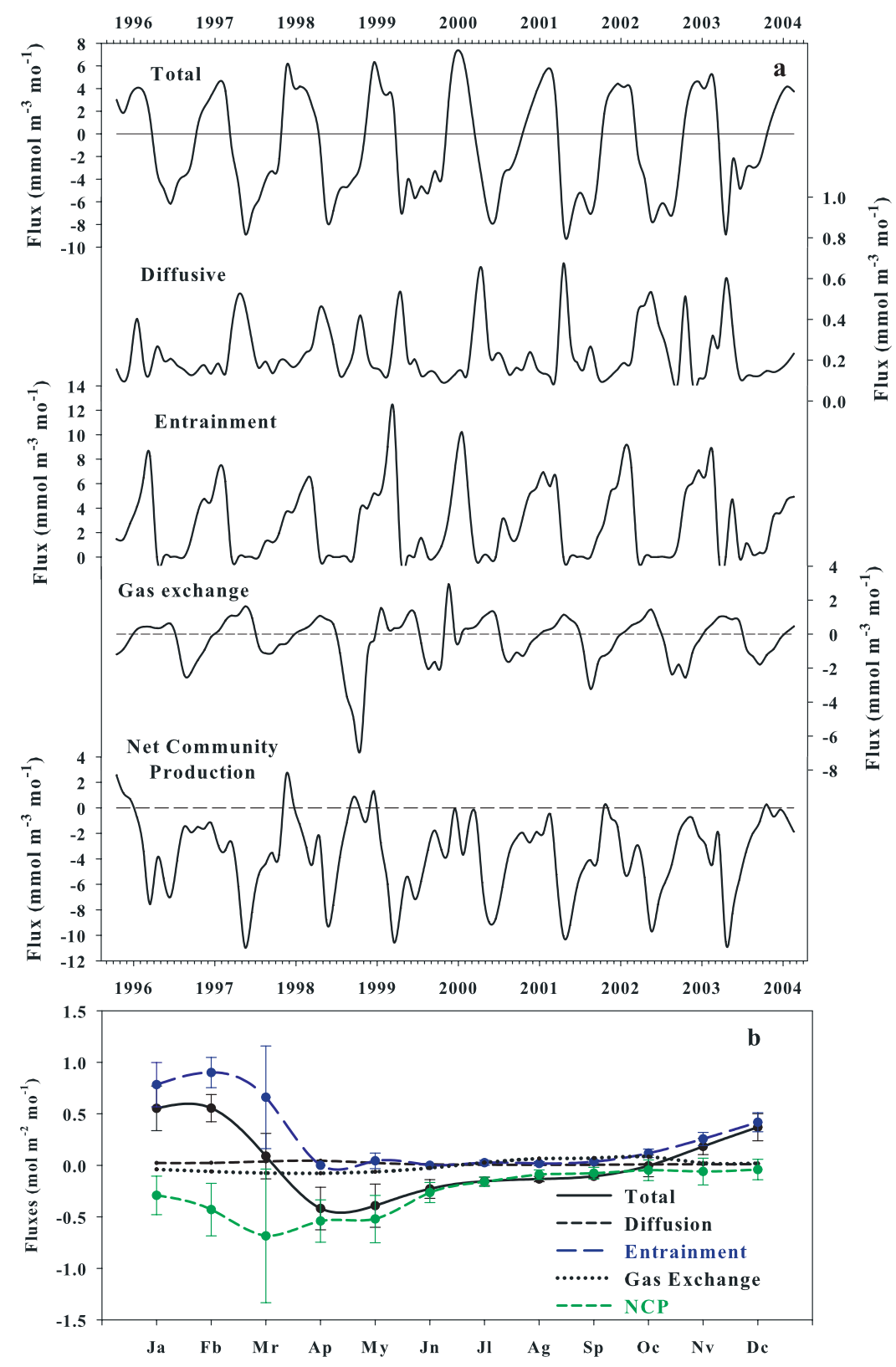

Figure 2. (a) Monthly fluxes of $\mathrm{CO}_{2}\left(\mathrm{mmol} \mathrm{m}^{-3} \mathrm{month}^{-1}\right)$ observed at the ESTOC site, and contributions computed by our decomposition model for diffusive transport, entrainment, gas exchange and net community production. Different scales are used for each contributor in order to emphasize seasonal variability. The monthly fluxes were evened out based on moving average T4253H (SPSS, version 13). (b) Mean monthly and long-term linearly de-trended fluxes of $\mathrm{CO}_{2}$ in the upper-ocean mixed layer $\left(\mathrm{mol} \mathrm{m}^{-2} \mathrm{month}^{-1}\right)$ from data in Figure 2a and mixed-layer depth values in Figure 1.

correlations with $\mathrm{Z}_{\mathrm{m}}(\mathrm{r}=0.45$ and $\mathrm{r}=0.47)$ and with temperature $(\mathrm{r}=-0.33$ and $\mathrm{r}=-0.23)$, clearly indicating that during cold-anomaly convective Winter periods (1999, 2000), there is an increased amount of $C_{T}$, due to deeper mixing and a biologically-induced drawdown of $\mathrm{C}_{\mathrm{T}}$ by net community production $\left(\mathrm{r}=-0.30\right.$ with $\mathrm{Z}_{\mathrm{m}}$ and $\mathrm{r}=0.40$ with $\mathrm{T}$ ). This interaction between the mixed-layer depth variability, entrainment and diffusion transport with biological activity (e.g., $r=-0.635$ between entrainment and biological drawdown anomalies, $r=-0.743$ when only the period from December to March is considered) also affects the magnitude of the seasonal cycle. During Winter 1999 (temperature anomaly of $0.7^{\circ} \mathrm{C}$ ) the anomaly in the entrain- ment flux was $200 \mathrm{mmol} \mathrm{m}^{-2}$ month $^{-1}$ whereas the net community production drawdown per month was up to $200 \mathrm{mmol} \mathrm{m}^{-2}$ month $^{-1}$ higher than average, primarily caused by the increased vertical supply of water from the thermocline, rich in nutrients. Years with shallow mixing, typically related to warmer surface waters (1997 with $\sim 0.9^{\circ} \mathrm{C}$ ), have a negative effect both on the $\mathrm{C}_{\mathrm{T}}$ flux due to entrainment and the $\mathrm{C}_{\mathrm{T}}$ drawdown due to biological activity [Keeling et al., 1995]. Moreover, the ESTOC site is also affected by the seasonal displacement of the Eastern subtropical gyre, which is stronger West of the Canary Islands, from October to March, while from April to September, the Southward transport is near the African coast, closely linked 


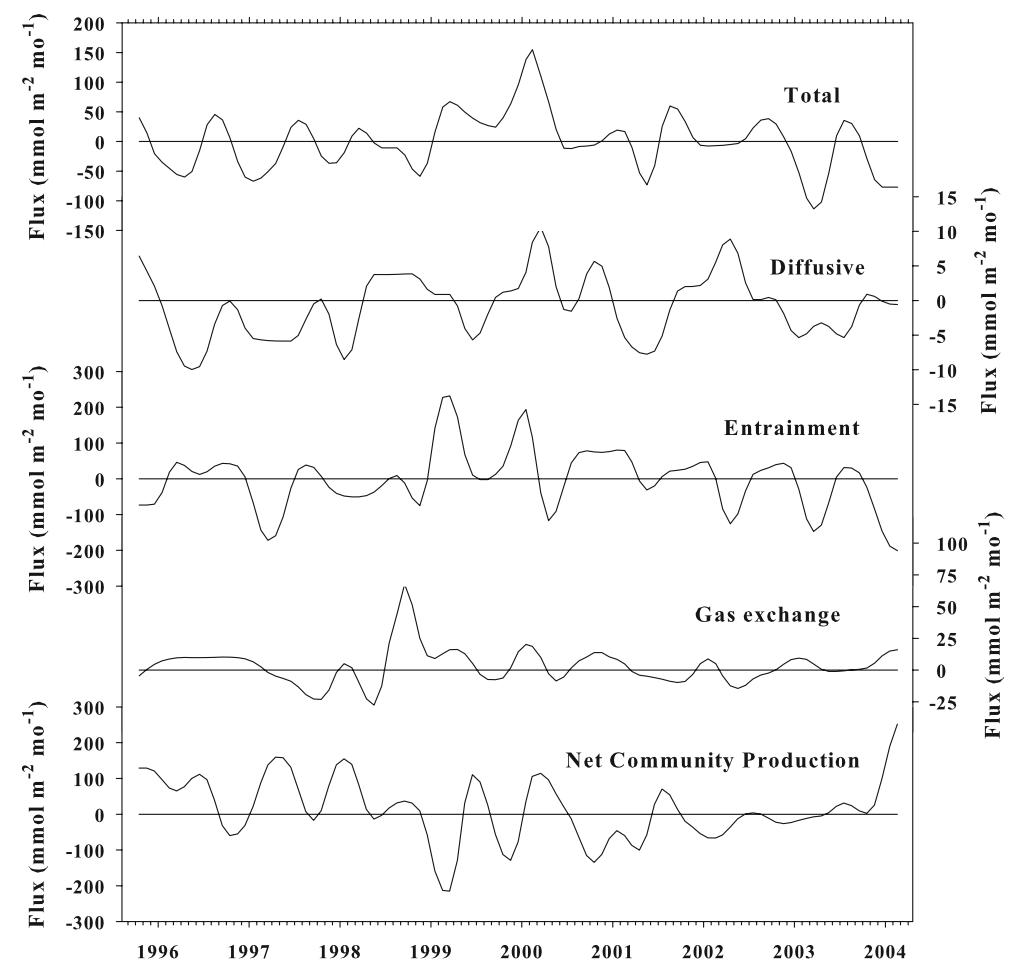

Figure 3. Observed and diagnosed interannual variability of anomalies in the monthly fluxes of $\mathrm{CO}_{2}$ observed at ESTOC. This was accomplished by fitting an ideal composite year to the series of experimental data in Figure 2a, after removing the interannual rate of change and computing residuals. The monthly anomalies were evened out based on moving average T4253H (SPSS, version 13). Different scales are used for each contributor in order to emphasize seasonal variability.

to the Trade Winds variability [Siedler et al., 2005]. This change around the Canary basin affects the surface water mass characteristics arriving at ESTOC, and may explain the anomaly in the distribution observed over the period, from the end of 1999 to early 2000.

[10] Table 1 shows the links between the NAO climate mode and the observed variability in the carbon cycle at the ESTOC site. The variability is generally slight. However, the Winter NAO index (December to March) exerts a strong influence on the climate in the North Hemisphere [Alfutis and Cornillon, 2001]. For the ESTOC site, none of our calculated quantities shows a correlation which is statically significant at $95 \%$ confidence level, except for in the case of the contribution of the diffusion anomaly. A significant correlation is obtained with a 3 year lag (NAO-3 index) for all the four contributors which is similar to that previously found for biogeochemical properties at ESTOC [Santana-Casiano et al., 2007], and for the correlation of both model and experimental results of baroclinic transport and spatial pattern for the Eastern part of the sub-tropical gyre with the NAO [Siedler et al., 2005; Eden and Jung, 2001]. The changes in wind stress due to the NAO will affect Ekman transports and pressure fields, and meridional shifts in circulation patterns can be expected [Visbeck et al., 2003]. The immediate and the delayed responses are different. The immediate change to a positive NAO, by the oceanic

Table 1. Correlations Between NAO and Various Observed Values (Temperature, Mixed Layer Depth, Total Inorganic Carbon, and Flux of Carbon Dioxide) and Diagnosed Flux Anomalies at the ESTOC Site

\begin{tabular}{llllllllll}
\hline Property & $\mathrm{SST}$ & $\mathrm{Zm}$ & $\mathrm{NC}_{\mathrm{T}}$ & $\mathrm{NC}_{\mathrm{T}}$ flux & Diff. & Ent. & Gas Ex. & $\mathrm{NCP}^{\mathrm{a}}$ & $\mathrm{NAO}^{\mathrm{N}} / \mathrm{NAO}_{\mathrm{w}} / \mathrm{NAO}_{\mathrm{w}}-3^{\mathrm{b}}$ \\
$\mathrm{SST}$ & 1.00 & $-0.34^{\mathrm{a}}$ & $-0.38^{\mathrm{a}}$ & 0.13 & $-0.23^{\mathrm{a}}$ & $-0.33^{\mathrm{a}}$ & $-0.34^{\mathrm{a}}$ & $0.40^{\mathrm{a}}$ & $-0.10 /-0.26 / 0.83^{\mathrm{a}}$ \\
$\mathrm{Zm}$ & & 1.00 & -0.02 & $0.37^{\mathrm{a}}$ & $0.47^{\mathrm{a}}$ & $0.45^{\mathrm{a}}$ & 0.11 & $-0.30^{\mathrm{a}}$ & $-0.01 /-0.01 /-0.64^{\mathrm{a}}$ \\
$\mathrm{NC}_{\mathrm{T}}$ & & & 1.00 & $-0.11^{\mathrm{a}}$ & 0.11 & -0.07 & $0.38^{\mathrm{a}}$ & 0.05 & $-0.01 /-0.10 /-0.26$ \\
$\mathrm{NC}_{\mathrm{T}}$ flux & & & & 1.00 & $0.42^{\mathrm{a}}$ & $0.53^{\mathrm{a}}$ & -0.05 & -0.07 & $0.27^{\mathrm{a}} / 0.74^{\mathrm{a}}-0.39^{\mathrm{a}}$ \\
Diff. & & & & & 1.00 & 0.06 & 0.15 & $-0.27^{\mathrm{a}}$ & $0.06 / 0.67^{\mathrm{a}} / 0.56^{\mathrm{a}}$ \\
Ent. & & & & & & 1.00 & 0.14 & $-0.64^{\mathrm{a}}$ & $0.01 / 0.39 /-0.93^{\mathrm{a}}$ \\
Gas Ex. & & & & & & & 1.00 & -0.30 & $-0.30 / 0.47 /-0.61^{\mathrm{a}}$ \\
$\mathrm{NCP}$ & & & & & & & 1.00 & $-0.03 /-0.21 / 0.81^{\mathrm{a}}$ \\
NAO & & & & & & & & \\
\hline
\end{tabular}

${ }^{\mathrm{a}}$ Correlations with $\mathrm{p}<0.05$.

${ }^{b}$ Data for NAO were obtained from http://www.cpc.noaa.gov/data/teledoc/ea.shtml. $\mathrm{NAO}_{\mathrm{w}}$ is the average of the values for the Winter season from December to March and NAO-3 is the $\mathrm{NAO}_{\mathrm{w}}$ with a time-lag of three years [Siedler et al., 2005; Eden and Jung, 2001]. 
horizontal circulation, is an anticyclonic anomaly centred near the sub-polar front. The delayed response to the surface heat fluxes changes in the sub-polar North Atlantic is a spinoff of both the sub-polar and the sub-tropical gyre, after about three years [Eden and Jung, 2001], which correlates to the ESTOC results.

[11] A similar analysis was carried out for the Western sub-tropical gyre, using carbon data from the Bermuda Atlantic Time-Series (BATS) site, and from Hydrostation "S" [Gruber et al., 2002; Bates, 2001]. The BATS and Station " $S$ " in combination, and the ESTOC site, share several similarities, but due to the Western location of the former within the Atlantic sub-tropical gyre, the seasonal cycle of heating/cooling is much higher at BATS, resulting in an increased annual cycle of $\operatorname{SST}\left(8^{\circ} \mathrm{C} v s .5^{\circ} \mathrm{C}\right)$ and much higher seasonal changes in mixed layer depth $(200 \mathrm{~m} \mathrm{vs}$. $150 \mathrm{~m})$ and $\mathrm{NC}_{\mathrm{T}}\left(30-40 \mu \mathrm{mol} \mathrm{kg}{ }^{-1}\right.$ vs. $\left.20-25 \mu \mathrm{mol} \mathrm{kg}^{-1}\right)$. The forcing of the SST on $f \mathrm{CO}_{2}$ appears to dominate over the forcing by $\mathrm{NC}_{\mathrm{T}}$ at both sites. Both sites show the most dominant interannual contribution to be entrainment, with a similar range of variability (Winter coefficients $r=0.46$ BATS and $r=0.55$ ESTOC). The variation in the NCP and the entrainment at ESTOC and near Bermuda are significant, correlating to variations in the mixed layer depths, with a tendency for higher values to be reached at ESTOC, probably due to the associated changes in entrainment of new nutrients in the upper ocean, in non-limited iron seawater, close to the African area. This circumstance could compensate for the shallower mixed-layer depth allowing for similar NCP values to be reached at both sites. BATS is defined as a net area of addition of carbon by gas exchange $\left(1.9 \pm 0.2 \mathrm{~mol} \mathrm{~m}^{-2}\right.$ year $\left.^{-1}\right)$ [Gruber et al., 2002] while ESTOC is characteristic of a region with slight $\mathrm{C}_{\mathrm{T}}$ addition $\left(0.05 \pm 0.02 \mathrm{~mol} \mathrm{~m}^{-2}\right.$ year $\left.^{-1}\right)$. The ESTOC site is affected by the predominant Trade winds blowing between May and September, just when the surface water is becoming $\mathrm{CO}_{2}$ oversaturated, counteracting the sinking effect. In both areas, the upper ocean carbon cycle tends to be weakened in warmer-, and intensified in colder- than- average years, due to the control exerted by the depth of the mixed layer variations on both entrainment and NCP, depending upon the magnitude of the seasonal cycle. The air-sea $\mathrm{CO}_{2}$ flux anomaly observed near BATS $\left( \pm 0.8 \mathrm{~mol} \mathrm{~m}^{-2}\right.$ year $\left.^{-1}\right)$, from 1982 to 1998 , is much higher than that observed at ESTOC $\left( \pm 0.1 \mathrm{~mol} \mathrm{~m}^{-2}\right.$ year $^{-1}$ ) from 1995 to 2004 . However, the strong control of the mixed layer depth variations in the $\mathrm{CO}_{2}$ fluxes on both sides of the sub-tropical gyre makes the pattern of anomalous $\mathrm{CO}_{2}$ flux for ESTOC consistent, in phasing, with those at BATS. The position of the stations, on both sides of the sub-tropical gyre, the different periods studied, and the relatively stable seasonal behaviour for the mean seasonal fluxes observed in shorter periods, seem to indicate that the anomaly observed at one site cannot be considered to be a representative value for the entire gyre as indicated in a previous piece of work [Gruber et al., 2002]. However, this does not mean that the observed flux anomaly at BATS may not be close to the one observed for the entire North Atlantic when inverse modelling analysis is applied [Gruber et al., 2002].

[12] These variations, together with the hydrographic and bio-geochemical properties of the surface ocean [SantanaCasiano et al., 2007], most likely reflect the NAO-related variations for both for BATS and ESTOC, with the Eastern sub-tropical gyre better correlated when a 3-year lag is considered. Interannual variability in the upper ocean carbon cycles at ESTOC, and near BATS, are mainly controlled by the strength of Winter convection which controls the mixed layer depth variations. These findings suggest that the ocean carbon cycle in the sub-tropical gyre may respond quite sensitively to future climate changes, but that the ESTOC variability may be predicted 3 years in advance.

[13] Acknowledgments. We are grateful to the captains and crews who have contributed to the work at the ESTOC station, and the commitment and effort of the many scientists and technicians involved in the data collection and sample analysis at ESTOC over the years. We thank Frank J. Millero, Liliane Merlivat, and Nick Bates for their helpful discussions. We also thank two anonymous reviewers who improved the original manuscript and M. Hart for correcting the English version. Supported by the Canary Island Government FLUCAN project dependent upon the Ministerio de Educación y Ciencia (REN2002-01548/MAR), and by the European Project CARBOOCEAN (511176-GOCE).

\section{References}

Alfutis, M. A., and P. Cornillon (2001), Annual and interannual changes in the North Atlantic STMW layer properties, J. Phys. Oceanogr., 31 2066-2086

Bates, N. R. (2001), Interannual variability of oceanic $\mathrm{CO}_{2}$ and biogeochemical properties in the western North Atlantic subtropical gyre, Deep Sea Res., Part II, 48, 1507-1528.

Bates, N. R., A. C. Pequignet, R. J. Johnson, and N. Gruber (2002), A short-term sink for atmospheric $\mathrm{CO}_{2}$ in subtropical mode water of the North Atlantic Ocean, Nature, 420, 489-493.

Bégovic, M., and C. Copin-Montegut (2002), Processes controlling annual variations in the partial pressure of $\mathrm{CO}_{2}$ in surface waters of the central northwestern Mediterranean Sea (Dyfamed site), Deep Sea Res., Part II, 49, 2031-2047.

Bjerkness, J. (1964), Atlantic air-sea interaction, Adv. Geophys., 10, $10-82$. Eden, C., and T. Jung (2001), Atlantic interdecadal variability: Oceanic response to the North Atlantic Oscillation, J. Clim., 14, 676-691.

Gloor, M., N. Gruber, J. Sarmiento, C. L. Sabine, R. A. Feely, and C. Rödenbeck (2003), A first estimate of present and preindustrial air-sea $\mathrm{CO}_{2}$ flux patterns based on ocean interior carbon measurements and models, Geophys. Res. Lett., 30(1), 1010, doi:10.1029/2002GL015594.

González-Dávila, M., J. M. Santana-Casiano, M. J. Rueda, O. Llinás, and E. F. González-Dávila (2003), Seasonal and interannual variability of seasurface carbon dioxide species at the European Station for Time Series in the Ocean at the Canary Islands (ESTOC) between 1996 and 2000, Global Biogeochem. Cycles, 17(3), 1076, doi:10.1029/2002GB001993.

Gruber, N., C. D. Keeling, and N. R. Bates (2002), Interannual variability in the North Atlantic Ocean carbon sink, Science, 298, 2374-2378.

Heimann, M. (1995), Dynamics of the carbon cycle, Nature, 375, 629-630.

Houghton, R. A. (2003), Revised estimates of the annual net flux of carbon to the atmosphere from changes in land use and land management 1850 2000, Tellus, Ser. B, 55, 378-390, doi:10.1034/j.1600-0889.2003.01450.x.

Hurrell, J. W. (1995), Decadal trends in the north Atlantic oscillation: Regional temperature and precipitation, Science, 269, 676-679.

Keeling, C. D., and T. P. Whorf (2000), The 1,800-year oceanic tidal cycle: A possible cause of rapid climate change, Proc. Natl. Acad. Sci. U. S. A., 97, 3814-3819.

Keeling, C. D., T. P. Whorf, M. Wahlen, and J. van der Plicht (1995), Interannual extremes in the rate of rise of atmospheric carbon dioxide since 1980, Nature, 375, 666-670.

Keeling, C. D., H. Brix, and N. Gruber (2004), Seasonal and long-term dynamics of the upper ocean carbon cycle at Station ALOHA near Hawaii, Global Biogeochem. Cycles, 18, GB4006, doi:10.1029/2004GB002227.

Llinás, O., A. Rodríguez de León, G. Siedler, and G. Wefer (1997), ESTOC Data Rep. 3, Inf. Tech. Inst. Canario Cienc. Mar., Telde, Spain.

Llinás, O., A. Rodríguez de León, G. Siedler, and G. Wefer (1999), ESTOC Data Rep. 7 (1995-1996), 152 pp., Inf. Tech. Inst. Canario Cienc. Mar., Telde, Spain.

Neuer, S., R. Davenport, T. Freudenthal, G. Wefer, O. Llinás, M. Rueda, D. K. Steinberg, and D. M. Karl (2002), Differences in the biological carbon pump at three subtropical ocean sites, Geophys. Res. Lett., 29(18), 1885, doi:10.1029/2002GL015393.

Neuer, S., et al. (2007), Biogeochemistry and hydrography in the eastern subtropical North Atlantic gyre: Results from the European time-series station ESTOC, Prog. Oceanogr., 72, 1-29. 
Raven, J., et al. (2005), Ocean acidification due to increasing atmospheric carbon dioxide, Rep. 12/5, R. Soc., London, U. K.

Sabine, C. L., et al. (2004), The oceanic sink for anthropogenic $\mathrm{CO}_{2}$, Science, 305, 367-371.

Santana-Casiano, J. M., M. González-Dávila, M.-J. Rueda, O. Llinás, and E.-F. González-Dávila (2007), The interannual variability of oceanic $\mathrm{CO}_{2}$ parameters in the northeast Atlantic subtropical gyre at the ESTOC site, Global Biogeochem. Cycles, 21, GB1015, doi:10.1029/2006GB002788.

Sarmiento, J. L., and N. Gruber (2002), Sinks for anthropogenic carbon, Phys. Today, 55, 30-36.

Siedler, G., A. Laurence, and T. J. Müller (2005), Meddies and decadal changes at the Azores Front from 1980 to 2000, Deep Sea Res., Part II, $52,583-604$.

Takahashi, T., S. C. Sutherland, C. Sweeney, A. Poisson, N. Metzl, B. Tilbrook, N. Bates, R. Wanninkhof, R. A. Feely, C. Sabine, J. Olafsson, and Y. C. Nojiri (2002), Global sea-air $\mathrm{CO}_{2}$ flux based on climatological surface ocean $p \mathrm{CO}_{2}$, and seasonal biological and temperature effects, Deep Sea Res., Part II, 49, 1601-1622.

Visbeck, M., E. Chassignet, R. Curry, T. Delworth, B. Dickson, and G. Krahmann (2003), The ocean's response to North Atlantic Oscillation Variability, in The North Atlantic Oscillation: Climatic Significance and Environmental Impact, Geophys. Monogr. Ser., vol. 134, edited by J. W. Hurrell, et al., pp. 113-146, AGU, Washington, D. C.

E. F. González-Dávila, Statistical Department, Faculty of Mathematics, University of La Laguna, La Laguna, Tenerife E-38201, Spain. (mgonzalez@dqui.ulpgc.es)

M. González-Dávila and J. M. Santana-Casiano, Chemistry Department, Faculty of Marine Science, University of Las Palmas Gran Canaria, Las Palmas de Gran Canaria E-35017, Spain. 